\title{
PENGARUH TERAPI MUSIK TERHADAP PERUBAHAN PERILAKU PENDERITA HALUSINASI PENDENGARAN PADA PASIEN SKIZOFRENIA: TINJAUAN LITERATUR
}

\section{The Effect of Music Therapy on Behavioral Changes in Auditory Hallucinations In Schizophrenic Patients: Literature Review}

\section{Tania Succi Dwi Apriliani ', Erna Tsalatsatul Fitriyah², Asri Kusyani²}

1. Mahasiswa S1 Keperawatan Stikes Bahrul Ulum Jombang

2. Dosen S1 Keperawatan Stikes Bahrul Ulum Jombang

\section{Riwayat artikel}

Diajukan: 18 Oktober 2020

Diterima: 11 Maret 2021

\section{Penulis Korespondensi:}

- Tania Succi Dwi Apriliani

- STIKes Bahrul Ulum Jombang

e-mail:

taniaaprilia129@gmail.c $\underline{\text { om }}$

Kata Kunci:

Schizoprenic, Auditory Hallucinations, Music Therapy

\section{Abstrak}

Pendahuluan: Skizofrenia adalah penyakit kronis yang dapat mempengaruhi semua aspek kehidupan seseorang. Skizofrenia sering diidentikan dengan halusinasi. Halusinasi merupakan presepsi yang diterima oleh panca indra tanpa adanya stimulus eksternal atau tidak nyata adanya. $70 \%$ penderita halusinasi mengalami halusinasi pendengaran. Terapi musik menjadi salah satu terapi yang menggunakan musik untuk memelihara atau memperbaiki mental, fisik, emosi, dan kebutuhan sosial. Tujuan: Tujuan dari literatur review ini adalah untuk menggali artikel tentang pengaruh terapi musik terhadap perubahan perilaku penderita halusinasi pendengaran pada pasien skizofrenia. Metode: Database yang digunakan dalam literatur review adalah google scholar dan portal garuda yang terseleksi berdasarkan diagram prisma flow dengan kriteria inklusi dan eksklusi, artikel diterbitkan pada tahun 2010-2020, menggunakan jurnal nasional dan internasional, artikel dengan menggunakan metode quasy experimen, true experimen, literatur review, dan narrative inquiry. Artikel full text, format pdf dan tidak berbayar. Hasil: Ditemukan dari 10 jurnal yang telah ditelaah bahwa terapi musik memiliki efek menurunkan tanda dan gejala halusinasi pendengaran, membuat pasien merasa nyaman, menurunkan kecemasan, mengurangi perilaku emosional dan dapat meningkatkan fungsi interpersonal. Saran: untuk penelitian selanjutnya, diharapkan melakukan penelitian mengenai jenis, durasi, frekuensi dalam pemberian terapi musik pada penderita halusinasi pendengaran pada pasien skizofrenia. Saran: untuk penelitian selanjutnya, diharapkan melakukan penelitian mengenai jenis, durasi, frekuensi dalam pemberian terapi musik pada penderita halusinasi pendengaran pada pasien skizofrenia.

\footnotetext{
Abstract

Background: Schizophrenia is chronic disease which can affect all aspects of a persons 's life. Schizophrenia often identified with hallucinations. Hallucinations is the perceptions received by the five senses whitout any external stimulus or not real. $70 \%$ hallucinations suffer from auditory hallucinations. Music therapy be a therapy that used music to maintain or improve mental, physical, emotional, and social needs. Objective: The purpose of this review literature is to explore articles about the effect of music therapy on behavioral changes in auditory hallucinations in schizophrenic patients. Method: the database used in this review literature is google scholar and portal garuda which selected by Prism Flow Diagram based on the inclusion and exclusion criteria, articles published in the year 2015-2020, using national and international journals, articles using experimental methods and review literature, article full text in pdf format and free. Result: Found 10 journals that have reviewed that music therapy has the effect of reducing signs and symptoms of auditory hallucinations, making patients feel comfortable, reducing anxiety, reducing emotional behavior, and improve interpersonal function. Suggestion: for future researchers, expected to cunduct research on the type, duration, frequency, in music therapy in patients with auditory hallucinations in schizoprenia patients.
} 


\section{PENDAHULUAN}

Gangguan jiwa adalah suatu perubahan pada fungsi jiwa yang menimbulkan penderitanya mengalami hambatan dalam melaksanakan peran sosial (Keliat, Akemat, Helena, Dkk, 2012). Gangguan psikosis yang umum adalah halusinasi, gangguan ini dapat mempersulit seseorang dalam bekerja dan belajar secara normal (WHO, 2019). Perubahan perilaku yang dapat muncul pada penderita halusinasi adalah curiga, ketakutan, perasaan tidak aman, gelisah, bingung, perilaku merusak diri, kurang perhatian, tidak mampu mengambil keputusan, dan tidak dapat membedakan keadaan nyata dan tidak nyata (Yosep \& Sutini, 2014).

Menurut Word Health Organization (WHO), (2019) memperkirakan orang dengan gangguan jiwa diseluruh dunia sebanyak 379 juta dengan 20 juta orang terkena skizofrenia psikosis. Data dari Hasil Riset Kebutuhan Dasar (Riskesdas) 2018 menunjukkan proporsi rumah tangga jumlah skizofrenia psikosis di Indonesia terdapat 282.654 orang dan 43.890 orang yang berada di Jawa Timur (Riskesdas, 2018).

Hasil penelitian yang dilakukan oleh Lewerissa, Dkk, (2019) terdapat perbedaan yang signifikan rata-rata perubahan Global Assessment of Functioning (GAF) Scale sebelum dan sesudah diterapi musik sebesar 5,50 dengan nilai $\mathrm{p}$ value 0,004 , yang artinya dapat menurunkan gejala dan meningkatkan fungsi pasien skizofrenia rawat inap di Rumah Sakit Daerah Provinsi Maluku. Respon penderita skizofrenia sanggat beragam saat terapi musik diberikan, ada yang merasa nyaman dan kecemasan mulai menurun.

Seiring dengan hasil penelitian yang dilakukan oleh Puspaningrum, Dkk, (2015) Terdapat pengaruh pemberian terapi musik klasik mozart trehadap kemampuan mengontrol halusinasi pada pasien halusinasi di Rumah Sakit Jiwa Dr. Amino Gondohutomo Provinsi Jawa Tengah dengan nilai $\mathrm{P}$ value 0,000 dengan nilai $\alpha<0,005$ dan $80 \%$ respondennya dapat mengontrol halusinasi yang sedang dialami.
Perawatan yang tepat dengan pemberian obat-obatan secara efektif, dukungan psikososial yang didapatkan secara baik dari lingkungan sekitar, pemberian terapi-terapi yang dapat mengembalikan keadaan orangorang yang terkena dampak pada keadaan yang produktif dan terintegritas dalam kehidupan masyarakat (WHO, 2019).

Salah satu terapi musik yang baik untuk penderita halusinasi pendengaran adalah terapi musik, karena dapat memperbaiki konsentrasi, ingatan, dan presepsi spasial (Purnama \& Rahmanisa, 2016). Berdasarkan uraian di atas, peneliti tertarik untuk menelaah beberapa jurnal untuk dijadikan literatur review mengetahui pengaruh terapi musik terhadap perubahan perilaku penderita halusinasi pendengaran pada pasien skizofrenia

\section{METODE}

Metode penelitian yang digunakan adalah Literature review yang dapat menjelaskan latar belakang penelitian suatu topik, alasan suatu topik penting untuk diteliti, menemukan hubungan antara study atau ide penelitian, mengidentifikasi tema, konsep, dan peneliti utama dalam satu topik, idenifikasi kesenjangan utama dan membahas pertanyaan peneliti lebih lanjut berdasarkan study sebelumnya (University of west florida, (2020) dalam Nursalam, (2020)). Database yang digunakan adalah Google Scholar dan Portal Garuda. Temuan dari beberapa database yang terseleksi berdasarkan diagram prisma flow dengan kriteria inklusi dan eksklusi. Kriteria eksklusi yang digunakan dalam Literatur review ini yaitu Primary source yang berhubungan dengan penggunaan terapi musik pada penyakit lain, jurnal yang digunakan diterbitkan pada tahun 2010-2020, jurnal yang digunakan berupa jurnal nasional dan internasional, dengan penelitian kuantitatif dan metode yang digunakan yaitu metode quasy eksperimen, true experimet, literature review, dan narrative inquery. Jurnal yang digunakan berbentuk pdf, full text, dan tidak berbayar. 
Kata kunci yang digunakan dalam pencarian jurnal yaitu, terapi musik, halusinasi pendengaran, dan skizofrenia

\section{HASIL PENELITIAN}

Proses pencarian jurnal dengan menggunakan database google scholar dan portal garuda dengan hasil pencarian awal sebanyak 3.869 jurnal. Selanjutnya jurnal dipilih dan disesuaikan dengan kriteria inklusi dan eksklusi. Dikeluarkan 104 jurnal karena diidentifikasi berdasarkan duplikasi sehingga tersisa 3.765 jurnal. Dari 3.765 jurnal kemudian diidentifikasi kembali berdasarkan judul jurnal dan hanya didapatkan 3.087 jurnal yang digunakan dan mengeluarkan 678 jurnal yang tidak digunakan. Kemudian, diidentifikasi kembali berdasarkan abstrak yng disesuakan dengan kriteia ekslusi dan didapatkan jurnal sebanyak 175 jurnal. Didapatkan 96 jurnal full text, lalu disesuaikan dengan kriteria eksklusi dan mendapatkan 10 jurnal yang sesuai dengan kriteria inklusi dan eksklusi yang akan digunakan sebagai bahan dalam kajian literatur review.

Berikut adalah diagram PRISMA flow dalam proses menemukan 10 jurnal (Lihat Gambar.1)

Gambar1. Diagram PRISMA Flow

\begin{tabular}{|c|}
\hline $\begin{array}{c}\text { database } \\
\text { Identification } \\
(\mathrm{n}=3.869)\end{array}$ \\
\hline $\begin{array}{c}\text { Dublication } \\
\text { Identification } \\
(\mathrm{n}=3.765)\end{array}$ \\
\hline $\begin{array}{c}\text { Title } \\
\text { Identification } \\
(\mathrm{n}=3.087)\end{array}$ \\
\hline $\begin{array}{c}\text { Abstract } \\
\text { Identification } \\
(\mathrm{n}=175)\end{array}$ \\
\hline \hline $\begin{array}{c}\text { Artikel full text } \\
(\mathrm{n}=96)\end{array}$ \\
\hline $\begin{array}{c}\text { Artikel full text di } \\
\text { telaah (n=10) }\end{array}$ \\
\hline
\end{tabular}

Ekslusi $(\mathrm{n}=2.912)$

1. Populasi

Responden tidak fokus variabel dependen

2. Intervensi dengan musik umum untuk penyakit umum

3. Tidak sesuai outcomes.

Eksklusi ( $\mathrm{n}=86)$ :

1. Primary source yang berhubungan dengan penggunaaan terapi musik pada penyakit lain

2. Artikel diterbitkan sebelum 2015

3. Artikel hanya mencantumkan abstrak dan berbayar.

Figure 1: PRISMA Flow diagram 
Jurnal Ilmiah Keperawatan (Scientific Journal of Nursing), Vol 7, No 1, Tahun 2021

Tabel 2: Hasil Studi Literature Pengaruh Terapi Musik Terhadap Perubahan Perilaku Penderita Halusinasi Pendengaran Pada Pasien Skizofrenia

\begin{tabular}{|c|c|c|c|c|c|}
\hline $\begin{array}{l}\text { Penulis } \quad \& \\
\text { Tahun }\end{array}$ & Judul & Tujuan & Metode & $\begin{array}{ll}\begin{array}{l}\text { Populasi } \\
\text { sampel }\end{array} & \& \\
\end{array}$ & Hasil \\
\hline $\begin{array}{l}\text { Rafina } \\
\text { damayanti, } \\
\text { Jumaini, \& Sri } \\
\text { utami. (2014) }\end{array}$ & $\begin{array}{l}\text { Efektifitas terapi } \\
\text { musik terhadap } \\
\text { penurunan } \\
\text { tingkat } \\
\text { halusinasi pada } \\
\text { pasien } \\
\text { halusinasi } \\
\text { dengar di RSJ } \\
\text { Tampan Riau }\end{array}$ & $\begin{array}{l}\text { Untuk mengetahui } \\
\text { efektifitas terapi } \\
\text { musik terhadap } \\
\text { penurunan tingkat } \\
\text { halusinasi pada } \\
\text { pasien halusinasi } \\
\text { dengar di RSJ } \\
\text { Tampan Riau }\end{array}$ & $\begin{array}{l}\text { Quasy } \\
\text { experiment }\end{array}$ & $\begin{array}{l}\text { Populasi: seluruh } \\
\text { pasien rawat inap } \\
\text { di ruang siak, } \\
\text { kuntan, sebayang, } \\
\text { unit perawatan } \\
\text { intensif psikiatri } \\
\text { Sampel: } 34 \text { pasien }\end{array}$ & $\begin{array}{l}\text {-Kelompok eksperimen }(\mathrm{p} \text { value }=0,003) \\
\text { dengan nilai alpha }<0.05 \\
- \text { kelompok kontrol (p value }=0,141) \\
\text { dengan nilai alpha }>0.05 \\
\text { Adanya penurunan tingkat halusinasi pada } \\
\text { kelompok eksperimen yang telah diberikan } \\
\text { terapi musik di RS Jiwa tampan Provinsi } \\
\text { Riau prodi Ilmu Keperawatan Universitas } \\
\text { Riau }\end{array}$ \\
\hline $\begin{array}{l}\text { Selma } \\
\text { Bozkurt } \\
\text { Zincir, } \\
\text { Serkan } \\
\text { Zincir, Ayril } \\
\text { Yenel, Yigit } \\
\text { Kivilcim, } \\
\text { Bugra Cetin, } \\
\text { Cumhur } \\
\text { Tulay, Umit } \\
\text { Bazar Semiz, } \\
(2014)\end{array}$ & $\begin{array}{l}\text { Musik turki } \\
\text { sebagai terapi } \\
\text { kelompok untuk } \\
\text { pasien rawat } \\
\text { inap dengan } \\
\text { kelayakan dan } \\
\text { kemanjuran } \\
\text { skizofrenia }\end{array}$ & $\begin{array}{l}\text { Mengetahui } \\
\text { kelayakan dan } \\
\text { kemanjuran } \\
\text { skizofrenia }\end{array}$ & True experiment & $\begin{array}{l}\text { Populasi = } 107 \\
\text { Sampel }=85\end{array}$ & $\begin{array}{l}\text { Penilaian kelompok kontrol dan kelompok } \\
\text { intervensi di dapatkan: } \\
\text { - } \quad \text { P value pada minggu pertama }=0,99 \\
\text { - } \quad \text { P value pada minggu kedua }=0,91 \\
\text { - } \quad \text { P value pada minggu ketiga }=0,02 \\
\text { - P value pada minggu keempat }=0,02 \\
\text { Dengan nilai alpha }<0,05 \\
\text { Pasien menunjukkan pengurangan gejala } \\
\text { kekerasan dan menunjukkan perbaikan } \\
\text { kemampuan adaptasi sosial dalam } \\
\text { lingkungannya }\end{array}$ \\
\hline $\begin{array}{l}\text { Arum Pratiwi, } \\
\text { Agus } \\
\text { Sudaryanto, } \\
(2015) .\end{array}$ & $\begin{array}{l}\text { Tingkat } \\
\text { penerimaan } \\
\text { terapi stimulasi } \\
\text { suara pada } \\
\text { pasien } \\
\text { halusinasi } \\
\text { dengar }\end{array}$ & $\begin{array}{l}\text { Menurunkan } \\
\text { tingkat } \\
\text { kekambuhan } \\
\text { pasien terhadap } \\
\text { pengalaman } \\
\text { halusinasi dengar }\end{array}$ & Narative inquery & $\begin{array}{l}\text { Populasi = semua } \\
\text { pasien dengan } \\
\text { skizofrenia } \\
\text { Sampel = } 10\end{array}$ & $\begin{array}{l}\text { Respon penderita skizofrenia dengan } \\
\text { halusinasi terhadap terapi musik berbeda- } \\
\text { beda . terapi musik sukses mengontrol } \\
\text { halusinasi dengan diagnosis tertentu. } \\
\text { Terapi stimulasi suara berhasil dan } \\
\text { menghilangkan halusinasi yang sedang } \\
\text { berlangsung pada pasien dengan diagnosa } \\
\text { medis skizofrenia undifferentiated. }\end{array}$ \\
\hline $\begin{array}{l}\text { Megan Hofer, } \\
(2016) .\end{array}$ & $\begin{array}{l}\text { The emotional } \\
\text { reactions of } \\
\text { music therapy } \\
\text { students to } \\
\text { stimulated }\end{array}$ & \begin{tabular}{lr}
\multicolumn{2}{c}{ Untuk mengetahui } \\
reaksi & emosional \\
siswa & terhadap \\
terapi & musik \\
dengan &
\end{tabular} & True experiment & $\begin{array}{l}\text { Populasi:total } \\
\text { sampel } \\
\text { Sampel:18 } \\
\text { partisipan }\end{array}$ & $\begin{array}{l}\text { Nilai P value pada: } \\
\begin{aligned} & \text { - } \\
\text { - } & \text { Pre post test: } 0,183 \\
& 0,41\end{aligned} \\
\text { Nilai } \alpha<0,5\end{array}$ \\
\hline
\end{tabular}


Jurnal Ilmiah Keperawatan (Scientific Journal of Nursing), Vol 7, No 1, Tahun 2021

\begin{tabular}{|c|c|c|c|c|c|}
\hline & $\begin{array}{l}\text { auditory } \\
\text { hallucinations } \\
\text { and music }\end{array}$ & $\begin{array}{l}\text { menstimulasi } \\
\text { halusinasi } \\
\text { pendengaran dan } \\
\text { musik }\end{array}$ & & & 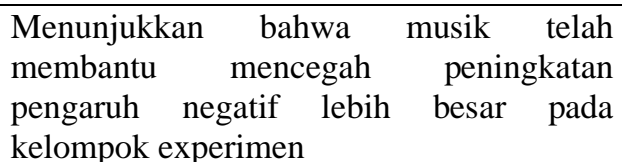 \\
\hline $\begin{array}{ll}\text { Wury } & \text { tri } \\
\text { wiyanto, } & \\
\text { Marisca } & \\
\text { agustina, } & \\
\text { (2017). } & \end{array}$ & $\begin{array}{l}\text { Efektifitas terapi } \\
\text { musik terhadap } \\
\text { penurunan tanda } \\
\text { dan gejala pada } \\
\text { pasien } \\
\text { halusinasi } \\
\text { pendengaran }\end{array}$ & $\begin{array}{l}\text { Mengetahui } \\
\text { Efektifitas terapi } \\
\text { musik terhadap } \\
\text { penurunan tanda } \\
\text { dan gejala pada } \\
\text { pasien halusinasi } \\
\text { pendengaran }\end{array}$ & $\begin{array}{l}\text { Quasy } \\
\text { experiment }\end{array}$ & $\begin{array}{l}\text { Populasi: } \text { Total } \\
\text { populasi } \\
\text { Sampel: } 30 \text { pasien }\end{array}$ & $\begin{array}{l}\text { Uji nomalitas: } \\
\quad-\quad \text { Pre: } P \text { value }=0,484 \\
-\quad \text { Post: } P \text { value }=0,204 \\
\text { dengan nilai alpha }>0,05 \\
\text { Menilai efektifitas } \\
P \text { value }=0,00 \text { dengan nilai Alpha }<0.05 \\
\text { Adanya Efektifitas terapi musik terhadap } \\
\text { penurunan tanda dan gejala pada pasien } \\
\text { halusinasi pendengaran di ruang rawat inap } \\
\text { Elang, Merak, dan Perkutut di RS Jiwa Dr } \\
\text { Soeharto Heerdjan Jakarta }\end{array}$ \\
\hline $\begin{array}{lr}\text { Rosiana, } & \\
\text { Jumaini, } & \text { Yesi } \\
\text { hasneli } & \text { N, } \\
(2018) . & \end{array}$ & $\begin{array}{l}\text { Efektifitas terapi } \\
\text { musik mozart } \\
\text { terhadap } \\
\text { penurunan skor } \\
\text { halusinasi } \\
\text { pendengaran } \\
\text { pada pasien } \\
\text { skizofrenia di } \\
\text { RS Jiwa tampan } \\
\text { Provinsi Riau } \\
\end{array}$ & $\begin{array}{l}\text { Mengetahui } \\
\text { efektifitas terapi } \\
\text { musik terhadap } \\
\text { penurunan skor } \\
\text { halusinasi } \\
\text { pendengaran pada } \\
\text { pasien skizofrenia }\end{array}$ & $\begin{array}{l}\text { Quasy } \\
\text { experiment }\end{array}$ & $\begin{array}{l}\text { Populasi: } \quad 348 \\
\text { pasien } \\
\text { Sampel: } 30 \text { pasien }\end{array}$ & $\begin{array}{l}\text { - kelompok eksperimen }(\mathrm{p} \text { value }=0,001) \\
\text { dengan nilai alpha }<0.05 \\
\text { - kelompok kontrol (p value }=0,786) \\
\text { dengan nilai alpha }>0.05 \text {. } \\
\text { Adanya penurunan skor halusinasi } \\
\text { pendengaran pada kelompok eksperimen } \\
\text { yang telah diberikan terapi musik di RS } \\
\text { Jiwa tampan Provinsi Riau prodi Ilmu } \\
\text { Keperawatan Universitas Riau }\end{array}$ \\
\hline $\begin{array}{l}\text { Peter } \\
\text { mosele, Ben } \\
\text { alderson } \\
\text { day, } \\
\text { Sukhbinder } \\
\text { kumar, } \\
\text { Charles } \\
\text { ferny hough, } \\
\text { (2018) }\end{array}$ & $\begin{array}{l}\text { Musical } \\
\text { hallusinations, } \\
\text { music imagery, } \\
\text { and earworms: } \\
\text { A new } \\
\text { phenemological, } \\
\text { survey }\end{array}$ & $\begin{array}{l}\text { Untuk mengetahui } \\
\text { pengaruh terapi } \\
\text { musik terhadap } \\
\text { mood dan perilaku } \\
\text { pada pasien } \\
\text { halusinasi } \\
\text { pendengaran. }\end{array}$ & $\begin{array}{l}\text { Quasy } \\
\text { experiment }\end{array}$ & $\begin{array}{l}\text { Populasi: } \\
\text { pastisipan } \\
\text { Sampel: } \\
\text { partisipan }\end{array}$ & $\begin{array}{l}\text { Nilai signifikan dalam pengaruh musik } \\
\text { terdahap perilaku antara lain: } \\
\text { 1. Respon menirukan lagu: } \mathrm{p}=0,001 \\
\text { 2. Respon motorik: } \mathrm{p}=0,001 \\
\text { Nilai } \alpha<0,0045 \text {. } \\
\text { Terapi musik mempunyai pengaruh dalam } \\
\text { pembentukan memori yang dapat } \\
\text { mengurangi efek kecemasan pada penderita } \\
\text { halusinasi pendengaran. }\end{array}$ \\
\hline $\begin{array}{l}\text { Sukran ertekin } \\
\text { pinar, Havva } \\
\text { tel, }(2018)\end{array}$ & $\begin{array}{l}\text { The effect of } \\
\text { music } \quad \text { on } \\
\text { auditory } \\
\text { hallucinations }\end{array}$ & $\begin{array}{l}\text { Untuk mengetahui } \\
\text { pengaruh musik } \\
\text { terhadap kualitas } \\
\text { hidup halusinasi }\end{array}$ & True experiment & $\begin{array}{l}\text { Populasi: semua } \\
\text { pasien halusinasi } \\
\text { pendengaran }\end{array}$ & $\begin{array}{l}\text { Penilaian pada kelompok experimen dan } \\
\text { kelompok kontrol } \\
\text { 1. Kelompok experimen : } \\
\text { - Aspek fisik: } 0,005\end{array}$ \\
\hline
\end{tabular}


Jurnal Ilmiah Keperawatan (Scientific Journal of Nursing), Vol 7, No 1, Tahun 2021

\begin{tabular}{|c|c|c|c|c|c|}
\hline & $\begin{array}{l}\text { and quality of } \\
\text { life in } \\
\text { schizophrenic } \\
\text { patients: A } \\
\text { randomised } \\
\text { controlled trial }\end{array}$ & $\begin{array}{l}\text { pendengaran pada } \\
\text { pasien skizofrenia }\end{array}$ & & $\begin{array}{l}\text { dengan } \\
\text { skizofrenia } \\
\text { Sampel: } 28 \text { pasien }\end{array}$ & $\begin{array}{l}\text { - Aspek mental: } 0,001 \\
\text { - Aspek sosial: } 0,349 \\
\text { - Aspek lingkungan: } 0,001 \\
\text { - Aspek lingkungan keseluruhan: } 0,001 \\
\text { 2. Kelompok kontrol: } \\
\text { - Aspek fisik: } 0,320 \\
\text { - Aspek mental: } 0,247 \\
\text { - Aspek sosial: } 0,960 \\
\text { - Aspek lingkungan: } 0,595 \\
\text { - Aspek lingkungan keseluruhan: } 0,381 \\
\text { Nilai } \alpha<0,05 \text {. } \\
\text { Mendengarkan musik pada nada suara rast } \\
\text { memiliki efek positif yang mana dapat } \\
\text { meningkatkan kualitas hidup menjadi } \\
\text { positif pada pasien halusinasi pendengaran. }\end{array}$ \\
\hline $\begin{array}{l}\text { Kyung hee } \\
\text { lee, Kyung ja } \\
\text { lee, Jung min } \\
\text { cho, (2018). }\end{array}$ & $\begin{array}{l}\text { Effect of korean } \\
\text { folk music } \\
\text { intervension on } \\
\text { schizophrenia } \\
\text { inpatients } \\
\text { emotional } \\
\text { behavior and } \\
\text { interpersonal } \\
\text { relationship } \\
\text { functioning }\end{array}$ & $\begin{array}{l}\text { Untuk mengetahui } \\
\text { pengaruh program } \\
\text { terapi musik } \\
\text { rakyat korea pada } \\
\text { perilaku } \\
\text { emosional dan } \\
\text { fungsi hubungan } \\
\text { interpersonal pada } \\
\text { pasien skizofrenia }\end{array}$ & $\begin{array}{l}\text { Quasy } \\
\text { experiment }\end{array}$ & $\begin{array}{l}\text { Populasi: semua } \\
\text { pasien skizofrenia } \\
\text { dir bangsal } \\
\text { psikiatri di daegu } \\
\text { Sampel: } 44 \text { pasien }\end{array}$ & $\begin{array}{l}\text { Kelompok expeimen } \\
\text { - Perilaku emosional ( } \mathrm{F}=5.814, \mathrm{p}<0.020) \\
\text { - Fungsi hubungan interpersonal }(\mathrm{F}=21.27 \text {, } \\
\mathrm{p}<0,001) \text {. } \\
\text { Menunjukkan bahwa program terapi musik } \\
\text { rakyat korea efektif untuk pemberian } \\
\text { intervensi dalam merubah perilaku } \\
\text { emosional dan meningktkan fungsi } \\
\text { hubungan interpersonal }\end{array}$ \\
\hline $\begin{array}{l}\text { Novita } \\
\text { susilawati } \\
\text { barus, Deborah } \\
\text { siregar, (2019). }\end{array}$ & $\begin{array}{l}\text { Efektifitas terapi } \\
\text { musik terhadap } \\
\text { halusinasi } \\
\text { dengar pada } \\
\text { pasien } \\
\text { skizofrenia }\end{array}$ & $\begin{array}{lr}\text { Menggati artikel } \\
\text { tentang efektifitas } \\
\text { terapi musik } \\
\text { terhadap } \\
\text { halusinasi } \\
\text { pada dengar } \\
\text { skizofrenia }\end{array}$ & Kajian literatur & $\begin{array}{l}\text { Menggunakan } 5 \\
\text { artikel }\end{array}$ & $\begin{array}{l}\text { Terapi musik dapat menurunkan intensitas } \\
\text { halusinasi pendengaran, memberikan rasa } \\
\text { nyaman dan menjadikan pasien tenang. } \\
\text { Pada kajian literatur review ini } \\
\text { teridentifikasi } 5 \text { artikel yang di review } \\
\text { dengan menunjukkan hasil beberapa } \\
\text { manfaat terapi musik terhadap halusinasi } \\
\text { pendengaran. }\end{array}$ \\
\hline
\end{tabular}




\section{PEMBAHASAN}

\section{Macam-Macam Terapi Musik Untuk Halusinasi Pendengaran}

Terapi musik adalah sebuah proses yang menggabungkan antara aspek penyembuhan dari musik itu sendiri dengan kondisi dan situasi yang dialami oleh klien, seperti kondisi fisik/tubuh, emosi, mental, spiritual, kognitif, dan kebutuhan sosial seseorang (Natalina, 2013). Ada beberapa musik yang dapat membantu dalam proses rehabilitasi pasien dengan halusinasi pendengaran, seperti, terapi musik klasik, terapi musik tradisional dan terapi musik secara umum.

Musik klasik adalah jenis musik yang menggunakan nada diatonis, yakni sebuah tangga nada yang menggunakan aturan dasar teori perbandingan serta musik klasik telah mengenal harmoni yaitu hubungan nada-nada dibunyikan serempak dalam akord-akord serta menciptakan struktur musik yang tidak hanya berdasar kepada pola-pola ritme dan melodi (Utomo, 2009 dalam Purnama \& Rahmanisa). Menurut Campbell (2010) dalam Purnama \& Rahmanisa (2016), Musik klasik Mozart atau Haydan mampu memperbaiki konesntrasi, ingatan, dan persepsi spasial. Pada gelombang otak, gelombang alfa mencirikan perasaan ketenangan dan kesadaran yang gelombangnya mulai 8 sampai 13 herts. Semakin lambat gelombang, semakin santai, semakain terasa damai, dan jika seseorang dalam kondisi melamun atau merasa dirinya berada dalam suasana hati yang emosional atau tidak terfokus, musik klasik dapat membantu memperkuat kesadaran dan meningkatkan organisasi mental seseorang jika mendengarkan selama 10-15menit.

Menurut Gerhard. T, (2006) dalam Zincir, Dkk (2014), Terapi musik tradisional berorientasikan sebagai sistem yang sudah tercatat selama lebih dari 100 tahun, alat terapi, pencegah rasa sakit, dan alat rehabilitasi yang relevan, seperti yang kita lihat saat ini yang terbukti menjadi yang terbaik dalam prakteknya. Dalam prakteknya terapi musik tradisional digunakan oleh rumah sakit sebagai acuan paramedic dan bagian seni pengobatan islam selama 9 abad. Pengaruh yang dihasilkan oleh terapi musik tradisional adalah mengembalikan semangat kemanusiaan, membangun sistem dalam diri, mengembalikan kulturasi kejiwaan.

Secara keseluruhan dapat disimpulkan bahwa terapi musik klasik lebih cenderung mempengaruhi kejiwaan berdasarkan sistem kerja neurologis. Sedangkan, terapi musik tradisional berorientasi pada sistem psikologi seseorang dalam memperbaiki sikap dan perilaku. Dalam hal lain musik pada umumnya memberikan nuansa kenyamanan yang ditimbulkan oleh tempo, beat, dan ritme berdasarkan kesukaan dari pasien.

\section{Pengaruh Pemberian Terapi Musik}

Tanda dan gejala yang muncul pada penderita halusinasi pendengaran yaitu berbicara sendiri, bersikap seperti mendengarkan sesuatu, berhenti berbicara saat ditengah-tengah kalimat untuk mendengarkan sesuatu, disorientasi, tidak mampu atau kurang konsentrasi, cepat berubah pikiran, alur pikir kacau, respon tidak sesuai, menarik diri, marah tanpa sebab dan sering melamun (Azizah, Dkk (2016). Penderita halusinasi pendengaran pada pasien dengan skizofrenia mempunyai tanda dan gejala yang beragam terkadang positif dan negatif untuk individu itu sendiri dan lingkungannya (Stuart, G. W, Dkk, 2016). Pemberian terapi musik menjadi salah satu pilihan yang digunakan dalam pemberian pengobatan non farmakologi yang dapat membantu penderitanya untuk menurunkan tanda dan gejala yang biasa terjadi (Purnama \& Rahmanisa, 2016). 
Didukung oleh penelitian dari Damayanti, Dkk, (2014) pasien yang sudah diberikan terapi musik klasik tampak fokus saat diajak berbicara, menjawab pertanyaan dengan benar, jarang berbicara sendiri, nyaman saat berinteraksi dengan orang lain dengan perbedaan hasil antara kelompok eksperimen dan kelompok kontrol dengan nilai $\mathrm{P}$ value $=0,000(\alpha<0,05)$. Terapi diberikan 5 kali dalam 5 hari selama 10-15 menit.

Penelitian yang dilakukan oleh Rosiana, Dkk, (2015) pasien yang sudah diberikan terapi musik mozart skor halusinasi pendengarannya menurun dengan perbedaan hasil antara kelompok eksperimen dan kelompok kontrol dengan nilai $\mathrm{P}$ value $=0,001(\alpha$ $<0,05)$. Terapi musik mozart mempunyai efek yang menjadikan pendengarnya merasa santai dan damai (Rosiana, Dkk, 2017).

Dari penelitian Wijayanto \& Agustina, (2017) terapi music efektif dalam menurunkan tanda dan gejala halusinasi dengan didapatkan hasil $\mathrm{P}$ value $=0,000(\alpha<0,05)$, terapi biberikan selama 10-15 menit. Penelitian lain juga mengatakan bahwasannya terapi musik dapat menurunkan tanda dan gejala halusinasi dengan hasil literatur review yang dilakukan oleh Barus \& siregar, (2019) dengan menunjukkan beberapa manfaat yang terjadi yaitu, menurunkan intensitas halusinasi pendengaran, menjadikan pasien nyaman dan pasien tenang.

Dari penelitian yang dilakukan oleh Pratiwi \& Sudaryanto, (2015) menyatakan bahwasannya dari 10 sampel yang diteliti 3 menyatakan lebih merasa nyaman saat terapi musik diberikan. 3 dari 10 pasien menyatakan kecemasan menurun saat diberikan terapi musik dan merasa lebih lega.

Dari penelitian yang dilakukan oleh Zincir, Dkk, (2014) menyatakan bahwasannya pasien mampu beradaptasi dengan lingkungannya setelah diberikan terapi musik klasik turki selama 1 bulan dengan waktu setiap satu minggu 3 jam dalam waktu 50-55 menit per sesi.

Penelitian lain yang dilakukan oleh Moseley, Dkk (2018) Terapi musik mempunyai pengaruh dalam pembentukan memori yang dapat mengurangi efek kecemasan pada penderita halusinasi pendengaran dengan pemberian terapi selama beberapa jam diterapkan per minggu dan dilakukan selama 1 bulan. Dari penelitian yang dilakukan oleh Pinar \& Havvatel (2018) terapi musik diberikan selama 15 menit saat pasien kambuh di Rumah Sakit, perubahan perkembangan perilaku direkap setiap 2 bulan sekali. Responden yang diberikan terapi musik dapat meningkatkan kehidupan pasien menjadi lebih positif.

Dari penelitian yang dilakukan oleh Hoffer megan (2016) dapat mengurangi efek emosional yang merugikan yang terkadang terjadi pada penderita halusinasi pendengaran dengan memberikan terapi music selama 3 bulan. Dari penelitian yang dilakukan oleh Lee. H, Dkk (2018) pemberian terapi musik rakyat korea pada penderita halusinasi pendengaran dengan skizofrenia dapat menurunkan perilaku emosional dan meningkatkan fungsi interpersonal dengan pemberian terapi music selama 8 Minggu, setiap minggu terdapat 2 sesi dengan durasi 50-55 menit per sesi.

Terapi musik biasa digunakan dalam pemberian intervensi pada penderita halusinasi pendengaran pada pasien skizofrenia karena dinilai sangat membantu dalam proses penyembuhan pasien. Hal tersebut sejalan dengan hasil penelitian terdahulu yang menyatakan bahwasannya terapi musik dapat merubah perilaku penderita halusinasi menjadi pasien merasa tenang, lebih kooperatif dalam melakukan aktifitasnya, menjadi fokus saat berbicara dengan orang lain, 
menjawab pertanyaan dengan benar, jarang berbicara sendiri, menjadi lebih rileks, mampu mengontrol halusinasinya, dan mampu beradaptasi dengan lingkungan sekitarnya. Menurut teori dan hasil penelitian terdahulu menunjukkan bahwa semua tanda dan gejala yang biasa terjadi pada penderita halusinasi pendengaran pada pasien skizofrenia terjadi perubahan setelah terapi musik diberikan.

\section{KESIMPULAN}

Pada kajian literatur review ini teridentifikasi 10 jurnal yang di review yang hasil review menunjukkan beberapa bentuk perubahan perilaku yang tejadi pada penderita halusinasi pendengaran pada pasien skizofrenia setelah diberikan terapi musik yaitu menurunkan tanda dan gejala halusinasi, membuat pasien merasa nyaman, menurunkan kecemasan, mengurangi perilaku emosional dan dapat meningkatkan fungsi interpersonal.

\section{SARAN}

Peneliti menyarankan bagi perawat terapi musik dapat digunakan sebagai bentuk promotif dan preventif pada halusinasi dengar selain pemberian pengobatan non farmakologi dengan durasi dan frekuensi yang sering dalam berbagai aktifitas yang yang dilakukan. Pada peneliti selnjutnya diharapkan untuk penelitian mengenai jenis, frekuensi, durasi musik yang efektif dalam merubah perilaku penderita halusinasi pendengan serta mencantumkan data hasil sebelum dan sesudah terapi musik diberikan.

\section{DAFTAR PUSTAKA}

Damayanti, R,. Jumaini, \& Utami, S. (2014). Efetifitas Terapi Musik Klasik Terhadap Penurunan Tingkat Halusinasi Pada Pasien Halusinasi Dengar di RSJ Tampan Provinsi Riau, (Online), (http://doi.org/10.1017/CB09781107 415324.004 diakses pada tanggal 21 Februari 2020, jam 10.00 WIB).
Geraldina. M. A (2017). Terapi Musik: Bebas Budaya Atau Terikat Budaya., (Online), (https://journal.ugm.ac.id/buletinpsik ologi/articel/view/27193 diakses pada tanggal 13 Februari 2020, jam 09.00 WIB).

Hoffer, M. (2016). The Emotional Reactions Of Music Therapy Students To Stimuled Auditory Hallucinations And Music, (Online), (https://diginole.lib.fsu.ede/islandora/ object/fsu\%3A360373 diakses pada tanggal 16 September 2020, jam 18.30 WIB).

Keliat,B. A., Akemat., Helena. C., Nurhaeni. H. (editor)., (2012). Keperawatan Kesehatan Jiwa Komunitas CMHN(Basic Course). Jakarta : EGC.

Lee, K. H., Lee, J. K., \& Cho, M. J. (2018). Effect Of Korean Folk Music Intervension On Schizophrenia Inpatients Emotional Behavior And Interpersonal Relationship Functioning, (Online),

(https://www.sciencedirect.com/scien ce/articel/abs/pii/S088394171930410

$\underline{8}$ diakses pada tanggal 19 September 2020, jam 19.00 WIB).

Lewerissa. S., Sherly. Y., Christiana. R. (2019). Pengaruh Terapi Musik Klasik Terhadap Penurunan Gejala Dan Fungsi Pada Pasien Rawat Inap Skizofrenia Di Rumah Sakit Khusus Daerah Provinsi Maluku, (Online), (https://ojs3.unpatti.ac.id/index.php/p ameri/articel/view/1291 diakses pada tanggal 10 Maret 2020, jam 17.30 WIB).

Moseley, P., Day, B., Kumar, S., \& Hough, C. (2018). Musical Hallucinations, Music Imagery, And Earwoms: A New Phenemological Survey, (Online)

(https://www.sciencedirect.com/scien ce/article/pii/S1053810018301600 diakses pada tanggal 19 September 2020, jam 18.00 WIB) 
Natalina,D., (2013). Terapi Musik Bidang Keperawatan. Jakarta : Mitra Wacana Medika.

Nursalam., (2020). Penulisan Literatur Review Dan Systematic Review Pada Pendidika Kesehatan (Contoh) . Surabaya: Fakultas Keperawatan Universitas Airlangga

Novita. B. S \& Deborah. S (2019). Kajian Literatur: Efektifitas Terapi Musik Klasik Terhadap Halusinasi Dengan Pada Pasien Skizofrenia, (Online), (https://ojs.uph.edu/index.php/NCJK/ articel/view/2313/840 diakses pada tanggal 06 Agustus 2020, jam 07.30 WIB).

Pinar, E., \& Tel, H. (2018). The Effect Of Music On Auditory Hallucination And Quality Of Life In Schizophrenic Patients: A Randomised Controlled Trial, (Online),

(https://www.tandfonline.com/doi/ful 1/10.1080/01612840.2018.1463324

diakses pada tanggal 16 September 2020, jam 08.30 WIB).

Purnama. M. D \& Rahmanisa. S (2016). Pengaruh Musik Klasik Dalam Mengurangi Tingkat Kekambuhan Penderita Skizofrenia Di Rumah, (Online),

(http://juke.kedokteran.unila.ac.id/ind ex.php/majority/articel/view/883/791 diakses pada tanggal 08 Januari 2020, jam 09.30 WIB).

Pratiwi. A \& Sudaryanto. A. (2015) Tingkat Penerimaan Terapi Stimulasi Suara Pada Pasien Halusinasi Dengar, (Online),

(https://injec.aipni-

ainec.org/index.php/INJEC/article/vie w/17/17 diakses pada tanggal 10 Agustus 2020, jam 08.00 WIB)

Riskesdas., (2018) Laporan Nasional Riskesdas 2018. Jakarta: Badan Penelitian dan Pengembangan Kesehatan (LPB).

Rosiana., Jumaini., Yesi. H. (2018) Efektifitas Terapi Musik Klasik Mozart Terhadap Penurunan Skor
Halusinasi Pendengaran Pada Pasien Skizofrenia, (Online),

(https://jom.unri.ac.id/index.php/JOM PSIK/article/download/19276/18631

diakses pada tanggal 15 Agustus 2020, jam 16.30 WIB)

WHO. (2019). Mental Disorder, (Online), (https://www.who.int/newsroom/fact-sheets/detail/mentaldisorder diakses pada tanggal 19 Februari 2020, jam 08.30 WIB).

Wijayanto, T. W \& Agustina, M (2017). Efktifitas Terapi Musik Klasik Terhadap Penurunan Tanda Dan Gejala Pada Pasien Halusinasi Pendengaran, (Online), (http://journals.stikim.ac.id/index.php /jiiki/article/view/234/171 diakses pada tanggal 20 Februari 2020, jam $10.00 \mathrm{WIB}$ )

Yosep,I \& Sutini,T., (2014). Buku Ajar Keperawatan Jiwa. Bandung : PT Refika Aditama.

Zincir, S., Zincir, S., Yenel, A., Kivilcim, Y., Cetin, B., Tulay, C., \& Semiz, B. (2014). Classical Turkish Music As Group Music Therapy For Inpatient With Schizoprenia: Feasibility Anf Efficacy, (Online), (http://www.journalijar.com/uploads/8 51 IJAR-3183.pdf di akases pada tanggal 20 Februari 2020, jam 11.30 WIB) 